\title{
Jezuitski kemiki v Habsburški monarhiji
}

\author{
Stanislav Južnič \\ *Corresponding author: E-mail: juznic@ hotmail.com \\ Telephone: 031814742
}

\section{Pozetek}

Opisani so dosežki jezuitov iz Avstrijske in Češke province, ki so objavljali knjige o kemiji. Posebej so izpostavljene njihove povezave z območjem današnje Slovenije. Nakazane so smernice s katerimi so omogočili uren prodor idej o strukturi snovi jezuita Ruđerja Boškovića. Nepojmljivo hitro uveljavljanje Boškovićevih pristašev v Habsburški monarhiji je primerjano s podobno hitro uveljavitvijo kinetičnih teorij atomov Slovenca Jožefa Stefana in z napol Slovenko poročenega Ludwiga Boltzmanna v istih zemljepisnih območjih.

Ključne besede: Jezuiti, Habsburška monarhija, zgodovina kemije, Ruđer Bošković, Jožef Stefan, Ludwig Boltzmann

\section{Uvod}

Srednja Evropa je v marsičem enaka ranjki Habsburški monarhiji. Jezuiti so v njej razvijali kemijske vede nekoliko mimo državnih meja, saj sta Avstrijska in Češka jezuitska provinca pokrivali tudi bavarski Passau in poljsko Šlezijo, ki jo je Mariji Tereziji »ukradel« Friderik Veliki. Po drugi strani pa je Tirolska pripadala Zgornjenemški provinci.

Razvoj kemije in sorodnih tehniških zanj v Avstrijski jezuitski provinci je bil $v$ veliki meri osredotočen na njen vzhodni z rudami bogati del v Slovaški in Transilvaniji, ki sta politično pripadali ogrski polovici Habsburške monarhije. Dunaj in Praga sta bila resda intelektualni središči, vendar pa sta sredi 18. stoletja svoje kemijskim uporabnim vedam namenjene spodbude prejemala predvsem od jezuitov odraslih in vzgojenih v rudarsko-industrijskih območjih Karpatov. Jezuitom se je ob Karpatih posrečilo razviti dve pomembni univerzi v slovaških Košicah in transilvanskem Cluju, sčasoma pa tudi v Bratislavi in danes ukrajinskem Uzhhorodu. Pomembno središče pod Karpati je bil jezuitski noviciat v Banski Bystrici, za razvoj kemije pa je bilo najpomembnejše Idriji sorodno rudarsko mestece Banska Štiavnica (Schemnitz) v katerem je Marija Terezija ustanovila svojo prvo Rudarsko akademijo s izbornimi profesorji med katerimi so bili dotedanji idrijski zdravnik-kemik Scopoli, nizozemski kemik Jacquin, nekdanji jezuit Ignaz von Born, ptujski jezuit Tirnberger in njegov sobrat Nikolaus Poda von Neuhaus. V danes slovenskih rudarskih središčih Idrijskega ali zasavskega območja jezuiti niso ustanovili svojih postojank, so pa o njih pisali in jih raziskovali tudi po kemijski plati; tu gre predvsem za dela, ki so jih postorili prvi eksperimentalni kemik vzgojen na danes slovenskem ozemlju Franz Muhlpacher in Tobija Gruber, brat bolj znanega Gabrijela.

\section{Začetki jezuitske kemije v Avstrijski in Češki provinci}

Jezuitska kemija se je, seveda, začela s svojo eksotično polsestro alkimijo, ki je imela mogočno podporo $\mathrm{v}$ cesarjih od praškega Rudolfa II. do dunajskega Leopolda I. Velik del alkimističnega početja je imel globokoumen značaj; njihova navezanost na uporabno kemijo industrijske proizvodnje in rudarjenja pa je bila temeljna, saj je bila osnova vseh alkimističnih pretvorb - idrijsko živo srebro. Bistven del jezuitskega uspeha pa so bile knjige o kemiji in drugih vedah, ki so jih naravnost množično proizvajali za večjo slavo svojega reda.

\section{Rimska naveza}

Sv. Ignacij je svojim jezuitom odsvetoval študij na medicinskih fakultetah, kar je bila mogočna cokla jezuitske kemije, ki se je med naprednimi Evropejci v veliki meri razvijala $\mathrm{v}$ povezavi $\mathrm{z}$ farmacijo in zdravljenjem. Ta nesmiselna prepoved je izvirala iz Ignacijeve osebne zamere do zdravnikov, ki mu med zdravljenjem $\mathrm{v}$ bojih poškodovane noge niso nikoli znali preprečiti šepanja, je delala preglavice mnogoterim generacijam jezuitov. Tako so Athanasius Kircher in njegova učenca Gaspar Schott v bavarskem Würzburgu ali Francesco Lana Terzi v Brescii svoje alkimistične razprave s praktičnimi navodili izdelave filozofskega kamna vred raje skrivali v mogočne knjige z drugačnimi zavajajočimi naslovi, saj si niso izrecno 


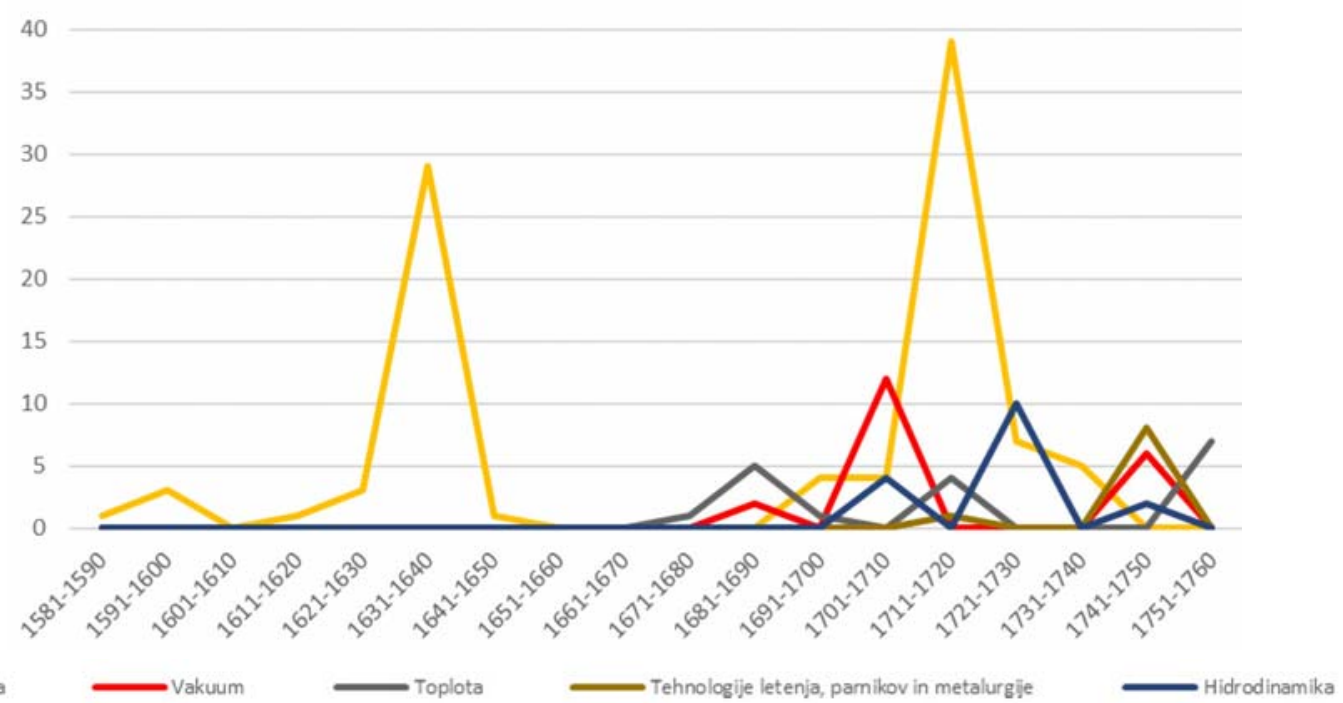

Graf 1: Število objavljenih kemijskih-fizikalnih knjig jezuitov avstrijske in češke province od skupno 616, med njimi 72 izpod peres ljubljanskih jezuitov, 29 pa od onih, ki so fiziko in/ali matematiko predavali tudi v Ljubljani.

želeli alkimistične slave. Kircher je svoje poglavitno alkimistično poglavje knjige Oedipus Aegyptiacus posvetil Janezu Vajkardu knezu Turjaškemu, ki je bil med smetano tedanje Evrope znan po svojih medicinskih in alkimističnih znanjih. Med svojo izmenjavo mnenj s praškim profesorjem Marcusim Marcijem je skoval temelje tedanjih alkimističnih kotenj. Lana Terzi je kakopak trdil, da je celo sam proizvedel »dušo zlata« in z njo izvedel par manjših transmutacij. ${ }^{1}$

\section{Nizozemska naveza}

Ob rimskem si velja ogledati še nizozemski vpliv na razvoj jezuitske kemije v Habsburški monarhiji; le-ta bi utegnil biti celo bolj merodajen in trajnejši, saj sta mu postavila piko na i komaj Van Swieten, Jacquin in Jan Ingenhousz ob zatonu jezuitskega reda.

Nizozemec španskega rodu Martin Del Rio je med prvimi zanesel nove kemijske in alkimistične prijeme $\mathrm{v}$ Avstrijsko jezuitsko provinco kot profesor v Gradcu. Ob nastopu v Gradcu je že imel v žepu prvo izdajo svoje najbolj odmevne knjige proti magiji, ki pa jo je strogo ločeval od alkimije; podpiral je možnost izdelave kamna modrosti. ${ }^{2}$ Iz Del Riovega okolja je izšel Francois d'Aguilon, ki je v Antwerpnu leta 1596 lastnoročno proizvajal zlato v posodah z jezuitskim žigom pred zvedavimi očmi očeta slikarja Rubensa in kemika Johannesa Baptiste van Helmonta. ${ }^{3}$ Francois d'Aguilon je nato objavil odmevno knjigo o optiki z Rubensovimi risbami in v svoji antwerpenskih učilnicah od leta 1611 ob pomoči Gregoira SaintVincenta izšolal številne jezuite Avstrijske in Češke province vključno s prvim olomuškim profesorjem fizike $s$ kemijo Theodorjem Moretom (Moretus) in vodilnim nizozemskim matematikom Andreé Tacqetom.
Med zgodnjimi jezuiti zainteresiranimi za alkimijo je bil antwerpenski jezuit Ignatius Derkennis (Der Kennis, * 1589; †1656), učenec raziskovalca kvadrature kroga Gregoira de Saint-Vincenta, ki se je svojih modrosti učil v Rimu pri Claviusu in Grienbergerju, čeravno je slednji nato kritiziral Saint-Vincentove prijeme. Saint-Vincent se je kemijskih modrosti navzel ob zatonu praškega alkimističnega okolja po smrti cesarja Rudolfa in po odhodu Johannesa Keplerja iz Zlatega mesta. Kot se to pogosto zgodi, je dobi globokoumnega iskanja vladarja Rudolfa in misleca Keplerja sledil rušilni napad nevednih pohlepnežev, za tisti nesrečni čas imenovan Tridesetletna vojna. SaintVincent je moral na vrat-na nos odpeketati iz zlate Prage kar brez zasnov svojih knjig. Podobno se je zgodilo drugemu velikemu sopotniku zgodnje kemije Athanasiusu Kircherju na Nemškem. Medtem ko je Kircher poslal ugledni rimski jezuitski profesor, se je Saint-Vincent raje vrnil domov na Nizozemsko in tam, med drugim, vzgojil Derkennisa. Derkennisova leuvenska predavanja so bila tako znamenita, da jih je obiskal celo škof Juan Caramuel Lobkowitz. Med Derkennisovimi študenti je bil tudi bodoči praški matematik Belgijec Joannes Weyer $(* 1598$; $\dagger 1575$ )

Derkennisova zgodnja jezuitska kemija s kritiko Descartesa in B. Pascalovih janzenistov je v avstrijski jezuitski provinci našla svoj odmev predvsem pri Gradčanu Leopoldu Galleru $(1683 ; \dagger 1761)$. Galler je o kemiji pisal kot dunajski profesor kemije in fizike znotraj filozofije leta 1718, desetletji pozneje pa je postal profesor starih spisov in knjižničar v Ljubljani leta 1736; njegov starejši brat Maksimilijan je bil dolgoletni profesor fizike s kemijo in ljubljanski rektor od 15. 11. 1716 do 24. 9. 1719. Oba imamo lahko za začetnika kemijskih snovanj med Slovenci pod vplivom dunajskega komerčnega svetnika od leta 1666 Johanna Joachima Bec- 


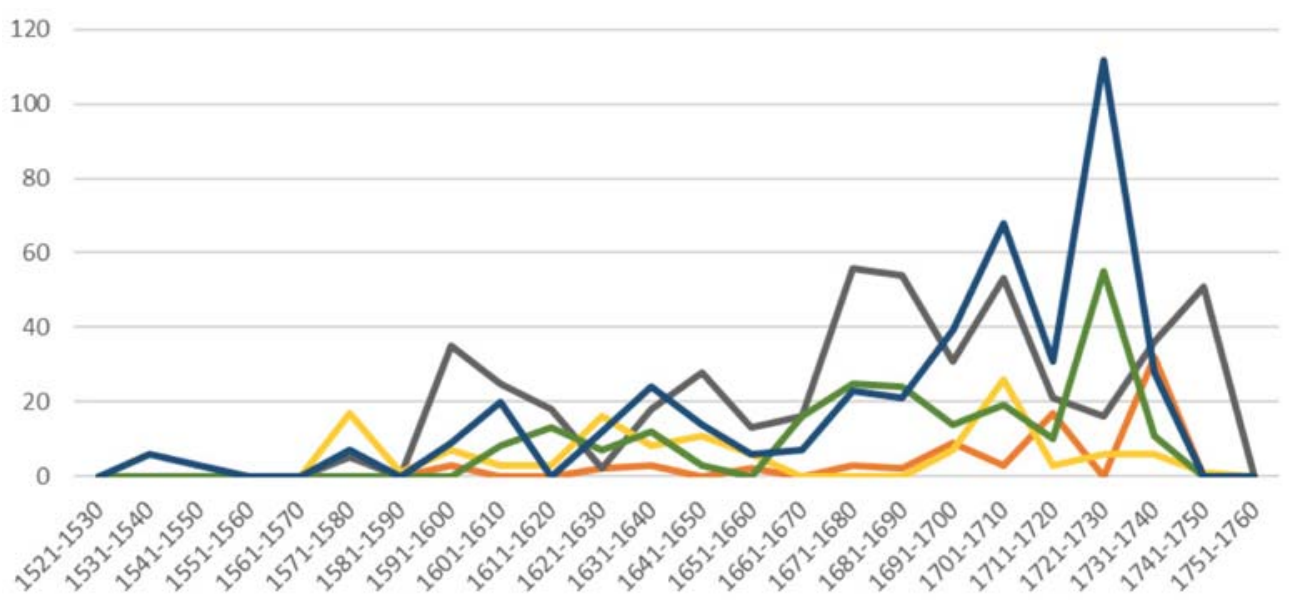

— Spodnještajerski profesorji: število letnikov predavanj filozofije s fiziko od skupno 76

Kranjski profesorji: število letnikov predavanj filozofije s fiziko od skupno 481

Goriški profesorji: število letnikov predavanj filozofije s fiziko od skupno 121

Koroški profesorji: število letnikov predavanj filozofije s fiziko od skupno 217

Hrvaški profesorji: število letnikov predavanj filozofije s fiziko od skupno 430

Graf 2: Domači kraji jezuitskih matematikov in fizikov-kemikov razporejenih po desetletjih rojstev.

herja $(* 1635 ; \dagger 1682)$. Becher je imel do leta 1675 podporo dunajskega prvega ministra Albrechta VII. prvega grofa Zinzendorfa-Pottendorfa $(* 1618 ; \dagger 1683)$, tekmeca žužemberško-ljubljanskega kneza Janeza Vajkarda Turjaškega. Janez je bil med dunajsko smetano daleč najvidnejši poznavalec medicine, alkimije in sodobnejšega eksperimentiranja in je do svoje odstavitve konec leta 1669 prav tako s prijaznim očesom opazoval Becherjeve domnevne tedaj zelo moderne transmutacije, v svojo ljubljansko knjižnico pa je uvrstil številne Becherjeve knjige, čeravno je bil Becher svojevrsten konkurent Janezovega favorita Athanasiusa Kircherja. Moža sta namreč zaporedoma objavila knjigi o kemiji podzemlja; potem ko je Kircher svojo knjigo naslovil Egipčanski Ojdip, mu je Becher pariral z naslovom Ojdip kemik. Iz Becherjevih snovanj je izšel flogiston Georga Ernsta Stahla $(* 1659 ; \dagger 1734)$ in opredelil kemijsko miselnost za več generacij do Lavoisierjevih dni.

Od Derkennisu je Leopold Galler navajal predvsem dela sobrata jezuita Thomasa Cevae (*1648 Milano; $\dagger 1737$ Milano), ki je deloval v tisti čas habsburškem Milanu pred prihodom svojega mlajšega sodobnika, jezuita Boškovića. Bil je brat matematika Johannesa Cevae (*1647 Milano; $† 1734$ Mantova). Thomas je nasprotoval tako Descartesu kot Koperniku, pač prisegajoč na sobrate jezuite, kot je bil Riccioli v Bologni. Zanimal se je za alkimijo slovitega ustanovnega člana londonske Kraljeve družbe Kenelma Digbyja. ${ }^{4}$

\section{Kemiki spod Karpatov}

Antonius Gabon (* 1677 Banská Bystrica na Slovaškem; †1735 Györ) je bil že znanilec novih časov v katerih alkimija in kemija nista več izhajali iz filozofskih pobud, temveč iz praktičnega industrijskega okolja blizu rudnika v Banski Štiavnici. Študiral je matematične vede pri dolgoletnem trnavskem profesorju Joannesu Dubovsky (Dobovski, Dubowsky), fiziko s kemijo pa pri Andreasu Madotsaniju (Madotsány). Prvo knjigo je kot profesor humanistike v Trnavi naslovil Žalostno razvedrilo ali Petero nespametnih o zaklenjenih modrostih, drugo pa je kot tamkajšnji profesor fizike s kemijo posvetil eksotični fiziki z naravnimi in umetnimi skrivnostmi narave. ${ }^{5}$ Opisal je kemijske postopke utemeljene na praktičnem znanju o živalih, žuželkah, barvah, rastlinah, drevesih, sadju in likerjih. Dodal je še uporaben slovar tehniških nazivov $\mathrm{v}$ štirih jezikih s katerimi je prihajal v stik: latinsko, madžarsko, nemško in češko.

Gabon je kot kratkohlačnik opazoval hrumenje turških čet, ki so skušale podjarmiti cesarski Dunaj kot ključ do oblasti v srednjeevropskem Podonavju. Seveda pa ni šlo zgolj za vojno, temveč predvsem za izmenjavo tehnoloških dosežkov dveh sicer sprtih kultur, ki se je, med drugim, izcimila tudi v nove dunajske obrede ljubiteljev kave. Orientalski vplivi so zasvojili dunajske tehniške vede predvsem z Josephusom Franzom (Frantz, * 1704; †1776) in Erazmom Frölichom. Franz je med prvimi na veliko prevajal iz 
turščine po obisku Carigrada leta 1740, ko mu je cesarica zaupala vodenje Orientalske akademije. Pisal je o astronomiji, še več pa o električnem telegrafu ob razmišljanjih o naravi elektrike. Svojih kemijskih zapiskov zvečine resda ni dal spustiti skozi tiskarske preše, a v njegovih časih so rokopisi prav tako urno krožili med znanja žejnimi bralci. ${ }^{6}$

Prvo sodobno kemijsko metalurgijo je med habsburškimi jezuiti objavil Hrvat $\mathrm{z}$ današnje meje med Slovaško in Ogrsko Josephus Bartakovics (Bartaković, * $1722 ; \dagger 1763)$. Matematične vede je leta 1742 študiral v Košicah pri Georgu Egererju, ki jih je predaval domala na vseh kolegijih Avstrijske province vključno z Ljubljano. Bartaković je kot mlad magister trnavski predavatelj po praktičnih izkušnjah nabranih že spod Karpatov objavil Metalurgijo s postopki pridobivanja zlata in srebra. Tako kot dve desetletji pred njim Gabon, je tudi Bartaković na konec postavil še slovar tehniških izrazov, vendar to pot zgolj trojezični brez češčine. Dodal je še analizo mineralnih voda, ki jih je bilo na njegovem območju obilo skupaj s številnimi toplicami. ${ }^{7}$

Bratislavčan Joannes Fridvalski (Fridvalszki, *1730; $\dagger 1784)$ je specializiral matematične vede na Dunaju pri Josefu Danielu, nato pa jih je desetletje predaval v transilvanskem Cluju. S terenskim delom se je dokopal do spoznanj o transilvanskem rudnem bogastvu, veliko pa je prispeval $\mathrm{k}$ kemijskim postopkoma za posodobitev izdelave papirja. Eksperimentiral je z rastlinami in popisal ogrske in transilvanske rudnike železa in železarne, predvsem pa njihove bogate lastnike. Prisegal je na mineraloški sistem Johna Henryja Gottloba de Justija (* 1717; †1771) objavljen pri göttingenski akademiji. Fridvalski je študiral fiziko s kemijo na dunajski univerzi leta 1751 pri promotorju Boškovičeve fizike Franciscusu Ginthörju (Gindhör) medtem ko je Justi predaval na sosednjem Terezijanišču od 1750 do 1753 v sodelovanju s poglavitnim terezijanskim politikom Friedrichom Wilhelmom grofom von Haugwitzom, vendar je Justi pozneje pri Frideriku Velikem potegnil ta kratko. Ravno med Fridvalskijevim študijem je Bavarec Ginthör prvi v Srednji Evropi promocijsko ponatisnil Boškovićevi knjigi o gravitacijskem pospešku v različnih točkah Geoida $v$ čast (in plačilo) študentu Josephu de Seppenburgu in o zametkih Boškovićeve teorije točkastih središč sil v čast (in plačilo) študentu Carlu de Reutterju (* 1734; $\dagger 1805) .{ }^{8}$ Reutter je bil promoviran v bakalavra pri Ginthörju že leta 1751 kot najstarejši sin dunajskega skladatelja Georga Reuterja (* 1708; †1772). Tudi sam je postal glasbenik violinist, kot cistercijan pa se je preimenoval v Marian(usa). ${ }^{9}$ Fridvalski in njegovi sošolci leta 1751 niso bili promovirani, na seznamu novih bakalavrov pa je bil med študenti-jezuiti le repetitor hebrejščine Karl Mayr.

Franciscusu Ginthör je bil mlajši brat knezoškofa in Passaua Josepha Antona Gindhöra (* 1713; †1791), leta $1738 / 39$ pa je v Ljubljani predaval humanistiko in vodil kongregacije. Po predavanjih fizike s kemijo v Passau in na Dunaju je postal profesor teologije, tato je vmesno predpostaviti, da ga je k promociji Boškovićevih del nagovoril so- delavec dunajski profesor matematike Karl Scherffer, ki se Ginthör prvi v Srednji Evropi promocijsko ponatisnil Boškovićevi knjigi o gravitacijskem pospešku v različnih točkah Geoida v čast (in plačilo) študentu Josephu de Seppenburgu in o zametkih Boškovićeve teorije točkastih središč sil v čast (in plačilo) študentu Carlu de Reutterju (* 1734; $\dagger 1805) .8$ Reutter je bil promoviran v bakalavra pri Ginthörju že leta 1751 kot najstarejši sin dunajskega skladatelja Georga Reuterja (* 1708; †1772). Tudi sam je postal glasbenik violinist, kot cistercijan pa se je preimenoval v Marian(usa).9Fridvalski in njegovi sošolci leta 1751 niso bili promovirani, na seznamu novih bakalavrov pa je bil med študenti-jezuiti le repetitor hebrejščine Karl Mayr.

Franciscusu Ginthör je bil mlajši brat knezoškofa in Passaua Josepha Antona Gindhöra (* 1713; †1791), leta $1738 / 39$ pa je v Ljubljani predaval humanistiko in vodil kongregacije. Po predavanjih fizike $\mathrm{s}$ kemijo $\mathrm{v}$ Passau in na Dunaju je postal profesor teologije, zato je vmesno predpostaviti, da ga je k promociji Boškovićevih del nagovoril sodelavec dunajski profesor matematike Karl Scherffer, ki se je pravkar vrnil na Dunaj z graške katedre za matematiko in astronomijo in je $\mathrm{v}$ naslednjih letih poslal poglavitni Boškovičev sodelavec in promotor. Leta 1751 je pri J. Danielu matematične vede specializiral Paul Mako, ki je kmalu postal vodilni zagovornik Boškovića. Fridvalski pa se je raje usmeril bolj v uporabne kmetijske vede.

Pri poskusih z železovo rudo in antimonom se je Fridvalski sklicaval na Boerhaaveja, pri svincu pa na Johannesa Kunckela. Živo srebro je skupaj z antimonom, bizmutom, cinkom in arzenom štel $\mathrm{k}$ semi-kovinam in ni pozabil navesti njegove uporabe $\mathrm{v}$ alkimiji. Transilvanska nahajališča arzena je hvalil že Šved Johan Gottschalk Wallerius (*1709; †1785), poskuse pa je objavil Lomonosov učitelj Johann Friderich Henckel. Fridvalski je opisal velika nahajališča nafte pod Karpati že pred B. Hacquetom, delal pa je tudi poskuse $\mathrm{z}$ destilacijo. Podobno kot tri desetletja pred njim Bartaković, je v zaključku popisal lokalne mineralne vode in toplice. ${ }^{10}$ Tik pred prepovedjo jezuitov je 24. 6. 1773 objavil še svoje poskuse s transilvanskim navadnim rujem »Rhus Cotinus Coriaria, Rhus Cotinus Linnaei« in ga primerjal s podalpsko, torej tudi $\mathrm{s}$ kraško Scopolijevo inačico. ${ }^{11}$

Gradiščan Matthaeus Pankel (Pankl, * 1740; †1798) je specializiral matematične vede pri poglavitnem trnavskem strokovnjaku Josefu Führerju. Fiziko z Lavoisierjevimi novostmi proti flogistonski kemiji je predaval $\mathrm{v}$ Trnavi, po preselitvi univerze pa ni odšel z njo v Budo, temveč je nadaljeval s predavanji v Bratislavi vse do svoje smrti. Takoj po Francoski revoluciji je objavil zajeten učbenik leta 1790, malo pred Lavoisierjevo smrtjo pa ga je leta 1793 prvič priredil za Lavoisierjevo kemijo brez flogistona po vzoru na dunajska nizozemska barona Jacquina. Panklov opis razvoja strukture svetlobe je citiral celo Goethe. Zelo odmevna je bila Panklova kmetijska kemija z madžarskim, latinskim in slovanskim kazalom; po njej so se zgledovali mnogi vključno s slovitim Liebigom 
in našim Matijo Vertovcem. ${ }^{12}$ Panklov fizikalno-kemijski učbenik je povzemal pri J. Horváthu ob hvali induktivne metode Newtona. Horváth je bil poglavitni zagovornik Boškovića, vendar je $\mathrm{v}$ ponatisu svojega učbenika leta 1790 že previdno izpustil Boškovićevo krivuljo kot odmev dejstva, da so jezuiti z Boškovićem vred počasi izgubljali prestiž pri pouku fizike in kemije. Pankel je med prvimi posebno poglavje posvetil novi znanosti - kemiji. V tretjem delu učbenika je dodal še nekaj geofizike, geologije, fiziologije, fizične geografije in kozmogonije. Ni citiral zgolj poglavitnih nizozemskih učenjakov Boerhaaveja in Muschenbroeka, temveč tudi najnovejše razprave na razmeroma sodoben način.

\section{Prostozidarska naveza}

Učitelj Gabrijela Gruberja in številnih drugih Nikolaus Poda von Neuhaus, (Boda(nus), * 4. 10. 1723 Dunaj; SJ 22. 1. 1740 Dunaj; † 29.4.1798 Dunaj) se je praktičnih astronomskih prijemov naučil pri M. Hellu, da je lahko prevzel vodenje sicer ne najbolj uspešne graške astronomske opazovalnice med letoma 1758-1765. Graška predavanja so se mu zdela premalo obetavna kljub Gruberju in drugim prvovrstnim študentom, zato je leta 1765 kot graški profesor objavil knjigo o okoliških štajerskih rudnikih. Knjiga je privlekla pozornost cesarice, ki ga je imenovala za profesorja na novo ustanovljeni Rudarski akademiji v Banski Štiavnici. Tako se je Poda praktičnega dela svoje kemije priučil kot profesor v Banski Štiavnici med letoma 1766-1771. Predaval je mehaniko in hidravliko, zato ga je še posebej zanimala rudniška črpalka, ki jo je izdelal Karl, brat cesarskega astronoma Maksimilijana Hella. Nabiranje ledu v ustju naprave zaradi tedaj še neznanega Joule-Thomsonovega ohlajanja zraka ob širjenju v prazen prostor je tista leta vzbudila ogromno prahu, od poročila francoskega obiskovalca Lavoisierovega akademskega tekmeca Gabrijela Jarsa, do polemičnih člankov Erazma Darwina in njihovih kritik s strani Tobije Gruberja. Poda je črpalko narisal in opisal njeno delovanje. ${ }^{13}$ Med delom v Banski Štiavnici, njega dni bolj znani po nemškem imenu Schemnitz, je začel svoje sodelovanje $\mathrm{z}$ velikanom tedanje habsburške kemije in uporabnih ved, transilvanskim prostozidarjem Ignazom von Bornon (* 1742; SJ 1760-1762; †1791). Born se je jezuitski družbi priključil zgolj za bora tri leta, nato pa sta preteči meč prepovedi družbe, ki se je udejanjil desetletje pozneje, in Bornova prirojena hudomušnost zahtevali razpotje. Born se je raje lotil sicer jalovega študija prava, kmalu pa je kot vodilni habsburški prostozidar urejeval naravoslovno glasilo in vodil svobodomiselni del politike in znanosti monarhije. Ni samo na novo izumil južnoameriškega amalgamiranja, temveč je o njem organiziral in vodil kar prvo znanstveno konferenco, ki je zgolj do neke mere spominjala na sodobne dogodke te vrste. Kljub prijateljstvu $\mathrm{s}$ Podo in objavljanju številnih jezuitskih prispevkov v svo- jem prostozidarskem glasilu je Born postal zapriseženi norčujoči se sovrag jezuitov in še posebej dvornega astronoma M. Hella. V svoji razporeditvi meniških redov po Linnéjevem vzorcu je medtem prepovedane jezuite resda izpustil, prostozidarski sobrat Mozart pa ga le ovekovečil v svoji Čarobni piščali. Podov sodelavec je bil tudi Franc Saleški Georg Eder (* 1738; †1788) s katerim sta leta 1776 na Terezijanišču sestavila seznam muzejskih fosilov. Eder je tam pravkar prevzel katedro za kemijo, metalurgijo in montanistiko, ki jo je obdržal ducat let vse do svoje smrti kot eden prvih profesorjev kemije v Habsburški monarhiji. Eder je svojo pedagoško pot začel leta 1763 in 1764 kot predavatelj gramatike v Ljubljani, tako da si lahko mislimo, da je obilico svojega kemijskega znanja zanesel tudi med Kranjce. ${ }^{14}$

Med poglavitne kemike nove dobe je spadal tudi Kranjec Frančišek pl. Mühlpacher (Millbacher, Mühlbacher, *1744; †1826). Kar dve leti je specializiral matematiko pri graškemu astronomu Aloisu Mayrju (*1731). Družba za kmetijstvo in koristne umetnosti ga je takoj po prepovedi jezuitov leta 1774 poslala popisovati kranjske naravne danosti skupaj z B. Hacqueton in ljubljanskim profesorjem kmetijstva Johanom Giehlom. Žal pa kot prvi ljubljanski eksperimentalni fizik in kemik Mühlpacher nikakor ni mogel priti do ustrezne namestitve v Ljubljani ne kot jezuit, ne po prepovedi reda, čeravno se je nekaj časa uspešno udinjal v G. Gruberjevi navigacijski komisiji. Po aneksiji Galicije je poprosil za pomoč brata, ki je dobil tam visok položaj. Tako je F. Mühlpacher postal leta $1775 / 76$ dolgoletni profesor kemije in vodja kemijskega laboratorija v Stanis ${ }^{3} a w o w u$, današnjem Ivano-Frankivsku v Ukrajini. Bil je prefekt gimnazije do upokojitve leta 1823, dne 16.9. 1818 pa je postal častni kanonik pa ukazu cesarja. ${ }^{15}$

Tudi Frančiškov mlajši sobrat Joannes Christophorus Stelzhamer (Stelzhammer, $* 1750 ; \dagger 1840)$ je specializiral matematiko pri graškemu astronomu Aloisu Mayrju. Rojen je bil na spodnjeavstrijskem gradu Weissenbach, ki ga je oskrboval njegov oče. Pri jezuitih je sledil zgledom svojega tri leta starejšega brata Paula. Prišel je v Ljubljano za predavatelja v prvem razredu; med ljubljanskimi srajcami je doživel dokaj blago prepoved jezuitov. Med letoma 1792-1797 je bil profesor fizike s kemijo v Celovcu, kjer je sodeloval s Sigmundom Hochenwartom s Kolovca pri Kamniku, poznejšim nadškofom Linza. Dunajskega matematika barona Metzburga in Boškovićevega prijatelja J. Liesganiga je spremljal pri geodetskih meritvah v poljski Galiciji do novembra 1796. Očitno se je dobro odrezal, saj je po obnovitvi Terezijanišča postal tam med letoma 1797-1825 profesor mineralogije in montanistike, nato pa še eksperimentalne fizike. Nadaljeval je z vodenjem laboratorija - muzeja po smrti avguštinca Andreasa Ksavierja Stütza (* 1747; †1806). Tam je samim presvetlim vojvodom kazal najnovejše kemijske poskuse tako prepričljivo, da je leta 1825 postal dekan dunajske filozofske fakultete in nato celo rektor. Med prvimi nekdanjimi jezuiti iz Av- 
strijske province je svoje domislice objavljal v sodobnih znanstvenih glasilih. Med drugim je nova letala dunajskega urarja Jakoba Degena (* $1760 ; \dagger 1848)$ opisal v Gilbertovih Analih ${ }^{16}$ še pred Degenovim slovitim poletom leta 1810, na Donavi pa je preizkušal prvi parnik potem ko je G. Gruber uspešno popravil poskuse na Muri.

\section{Prodor novih teorij sestave snovi v obdonavski habsburški jezuitski prostor: Bošković}

Medtem ko je nastajajoča poznobaročna kemija nezadržno polzela spod rok jezuitov v naročje novodobnih

Preglednica 1: Podporniki sprva zelo uspešne Boškovićevega opisa točkaste neskončno deljive. Po njegovem dunajskem obisku (1757-1758) so si hitro večino pomembnih akademskih položajev v Habsburški monarhiji

\begin{tabular}{|c|c|c|c|}
\hline Ustanova & $\begin{array}{l}\text { Leto } \\
\text { imenovanja } \\
\text { Stefanovega } \\
\text { podpornika }\end{array}$ & Stefanov zagovornik & Stefanov nasprotnik \\
\hline Dunajska Univerza & $1857 ; 1863$ & $\begin{array}{l}\text { Ettingshausen z zetom Grailichom; Stefan, } \\
\text { Loschmidt }\end{array}$ & Mach 1895-1898 \\
\hline Dunajska Politehnika & $1816-1845$ & Študentje Johanna Philipa Neumanna & \\
\hline $\begin{array}{l}\text { Therezijanišče } \mathrm{z} \\
\text { diplomatsko Akademijo }\end{array}$ & & $\begin{array}{l}\text { Študent Tivadar Puskás, ki je pozneje zaposlil } \\
\text { N. Teslo v Budimpešti }\end{array}$ & \\
\hline Akademija Dunaj & $1863 ; 1865$ & Stefan & Andreas von Baumgartner, Mach \\
\hline Univerza Gradec & $\begin{array}{l}1864-1865 ; \\
1869\end{array}$ & $\begin{array}{l}\text { Viktor von Lang; Ludwig Boltzmann, } \\
\text { Klemenčič }\end{array}$ & Mach (1865-1867), Simon Šubic \\
\hline Gradec Politehnika & $1865-1871$ & Ferdinand Lippich & \\
\hline $\begin{array}{l}\text { Štajerska naravoslov } \\
\text { na družba v Gradcu }\end{array}$ & 1869 & Boltzmann & Šubic \\
\hline Buda Gimnazija & & & Šubic \\
\hline Buda Politehnika & 1872 & Kololman Szigeth Szily (Kálmán, * 1838; †1924) & \\
\hline Univerza Pešta & & Študent Otta Petzvala Loránd baron Eötwös & \\
\hline Realka Pešta & & & $\begin{array}{l}\text { Šubic, N. Teslov } \\
\text { profesor Martin Sekulić }\end{array}$ \\
\hline Nemška Univerza v Pragi & $1874-$ & Lippich & Mach $1867-1895$ \\
\hline Praška Politehnika & $1865-$ & & Schmidt \\
\hline $\begin{array}{l}\text { Praška Královska Česká } \\
\text { společnost nauk }\end{array}$ & 1864 & & Baumgartner \\
\hline Univerza Lvov & $1862-1872$ & & Alois Handl \\
\hline Univerza Czernovicz & & & Alois Handl \\
\hline Univerza Innsbruck & 1895 & Ignac Klemenčič & \\
\hline Realka Ljubljana & $1870-1874$ & Joseph Finger & \\
\hline $\begin{array}{l}\text { Ljubljana Gimnazija, } \\
\text { nato mariborsko učiteljišče }\end{array}$ & 1873 & Luka Lavtar & \\
\hline Realka Maribor & 1877 & Robert Spiller & \\
\hline Maribor Gimnazija & 1891 & Josef Hirschler & \\
\hline Novo Mesto Gimnazija & $1851-1884$ & Klemenčičev profesor Bernard Vovk & \\
\hline Gorizia Gimnazija & 1872-1907 & Anton Šantel & \\
\hline Celovec Gimnazija & $\begin{array}{l}1845-1878 \\
1873-1783\end{array}$ & $\begin{array}{l}\text { Vincenc Borštner, } \\
\text { profesor Josipa Plemlja }\end{array}$ & Karl Robida \\
\hline $\begin{array}{l}\text { Univerza Pavia, } \\
\text { Univerza Milano } \\
\end{array}$ & & $\begin{array}{l}\text { Zagovorniki pavijskega študenta Gabria } \\
\text { grofa Priola (1794-1850) }\end{array}$ & \\
\hline Koper Gimnazija & $1858-1863$ & Nicolo Vlacovich & \\
\hline Zagreb Univerza & $1874-1911$ & & $\begin{array}{l}\text { Nekdanji Machov praški asistent } \\
\text { Vinko Dvořák }\end{array}$ \\
\hline$\overline{\text { Mestna višja realka Trst }}$ & $1863-1885$ & Nicolo Vlacovich & \\
\hline $\begin{array}{l}\text { Dresden Politehnika } \\
\text { in Tehniška visoka šola }\end{array}$ & & August Toepler 1876-1900 & Energetik Georg Helm 1888-1919 \\
\hline Leipzig Univerza & & Boltzmann 1900-1902 & Wilhelm Ostwald \\
\hline
\end{tabular}




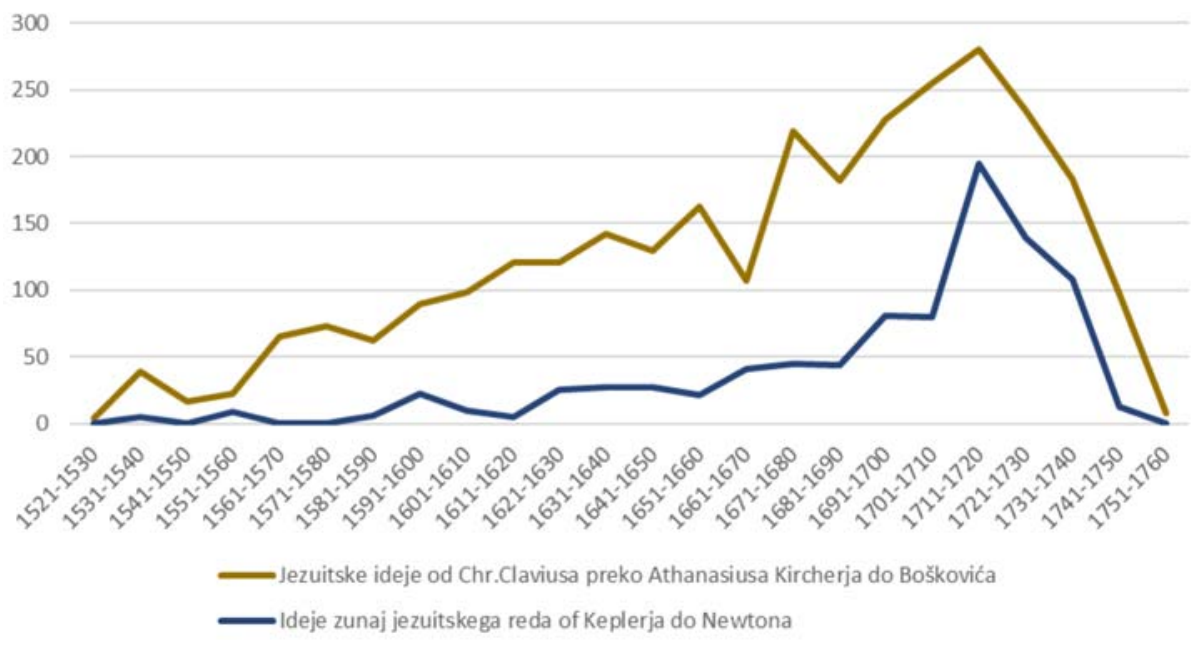

Graf 3: Spreminjanje fizikalnih idej poldrugih tisoč jezuitskih profesorjev matematike-fizike iz avstrijske in češke province po dekadah rojstva. Pomembnost profesorjev je ocenjena od 1 do 9 glede na pisana dela, pomembne katedre, važne službe in plemiški stan.

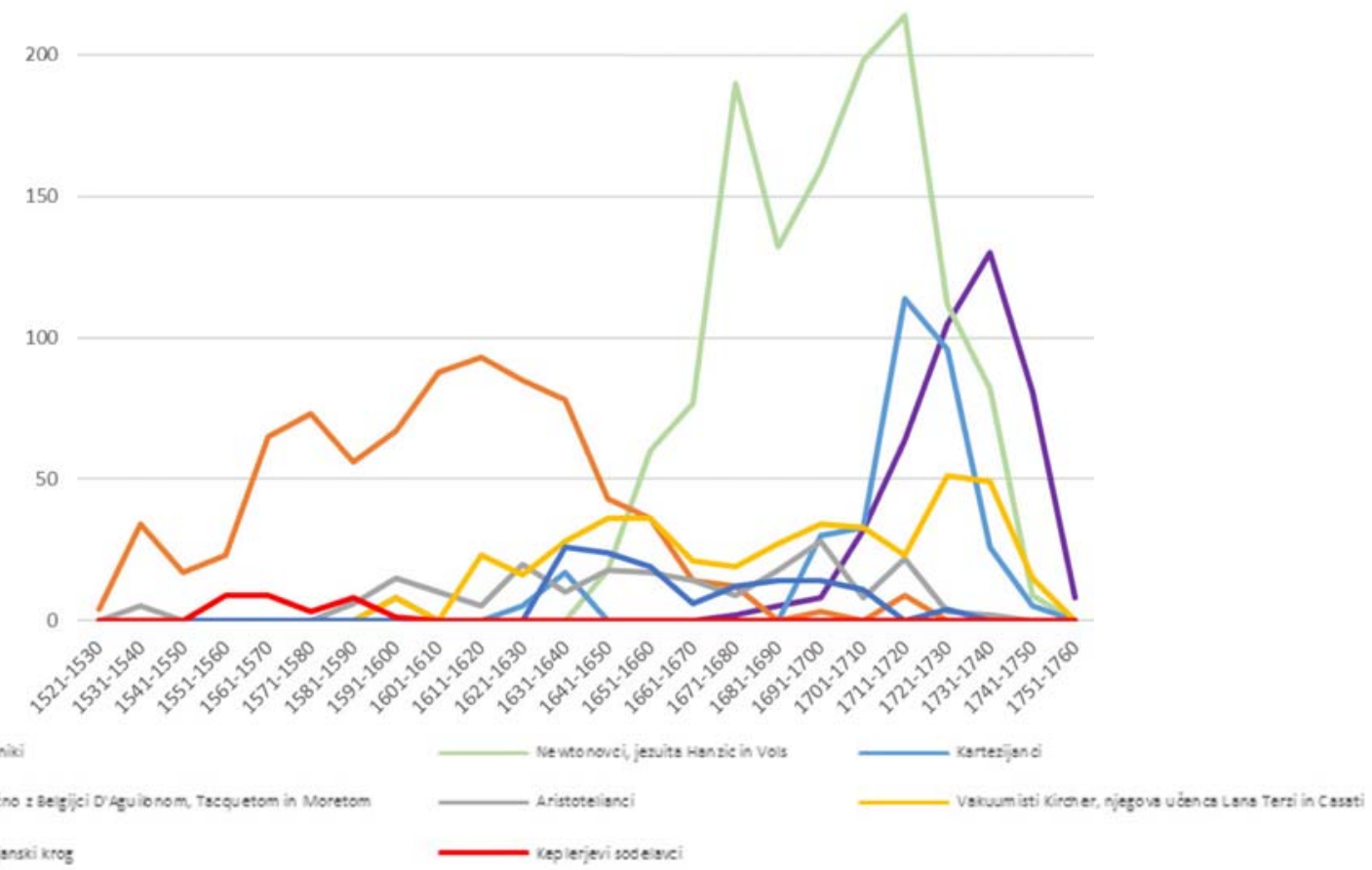

Graf 4: Spreminjanje fizikalnih idej poldrugih tisoč jezuitskih profesorjev matematike in fizike iz avstrijske in češke province med katerimi jih je sto predavalo fiziko in matematiko tudi v Ljubljani glede na dekade njihovega rojstva.

prostozidarskih učenjakov zvrsti nekdanjega jezuita Borna, je jezuitski labodji spev obrodil prodorno Boškovičevo teorijo neskončno deljive snovi sestavljene iz brez- dimenzijskih središč sil. Jezuit Bošković je leta 1758 na Dunaju objavil svojo poglavitno knjigo in z njo v nekaj letih dobesedno pometel $\mathrm{z}$ vsemi nasprotniki in dvomljivci $\mathrm{v}$ Srednji Evropi. V Italiji in drugod nikakor ni bil tako uspešen, zato je $\mathrm{z}$ velikim olajšanjem sprejel katedro $\mathrm{v}$ tedaj habsburški Pavii. Seveda je bilo tudi pod habsburškim žezlom nekaj nasprotnikov, ki so Boškovićevi kemiji in fiziki kljubovali, med njimi predvsem, J. Stepling na
Klementinumu Zlati Pragi in cesarski astronom doma iz Banske Štiavnice Maximilian HelI. Oba nasprotnika sta bila vsak po svoje vplivna. Kljub temu pa so bili njuni dvomi bolj kaplja v morje Boškovićevih občudovalcev, ki jih je prepoved jezuitskega reda sicer zavrla $v$ vseevropski ekspanziji, nikakor pa jih ni onesposobila. Narodnostno in idejno mešana struktura Donavske monarhije pod habsburškim srednjeevropskim žezlom se je izkazala kot idealno okolje za tovrstne bliskovite spremembe $\mathrm{v}$ dojemanju kemijske strukture snovi. Seveda že itak nestrpni Bošković ni mogel biti povsem zadovoljen, saj so bile zgodnje 
kritike njegove neskončno deljive snovi dovolj tehtne, da so to plat njegove kemije srednjeevropski učenjaki najraje izpustili, čeravno so sicer sledili Boškovićevemu nauku. Kot se pogosto zgodi, se je lastna teorija izmuznila Boškovićevi kontroli in zaživela lastno življenje podložno tudi spremembam, ki so bile Boškoviću zoprne, denimo tiste spod gosjega peresa soodkritelja kisika Josepha Priestleya na katere se je Bošković ostro odzval tudi z nizkimi udarci s pritožbami pri Priestleyevem delodajalcu.
Tako je tudi med kranjskimi frančiškani zelo vpliven Kastul Hieber (Castulus, * 1761 München; OFMobs 1780; † 18. 8.1810 Ingolstadt) iz Chama severovzhodno od Regensburga izrecno nastopil proti Boškovićevi neskončni deljivosti snovi, čeravno je novomeški profesor matematike in grččine Teofil Zinsmeister (Franc, * 2. 11. $1777 \mathrm{Ba}-$ varska; OFM 10. 10. 1796; † 12.11. 1817 Novo Mesto) pod Hieberjevim vplivom v svojem rokopisnem učbeniku navdušeno risal znamenito Boškovićevo krivuljo. ${ }^{17}$

Preglednica 2: Boškovićevi podporniki na ključnih akademskih položajih v Srednji Evropi

\begin{tabular}{|c|c|c|c|}
\hline Ustanova & $\begin{array}{l}\text { Leto prve } \\
\text { katedre } \\
\text { Boškovićevega } \\
\text { podpornika }\end{array}$ & Boškovićevi podporniki & $\begin{array}{l}\text { Boškovićevi } \\
\text { nasprotniki }\end{array}$ \\
\hline Univerza Dunaj & $1751-1773$ & $\begin{array}{l}\text { Joseph Xavier Liesganig, Scherffer (1751-1783); } \\
\text { Piarist Johan Nepomuk Alber (7. 6. } 1753 \\
\text { Mosonmagyaróvár; } † \text { 7. 7. 1753 Pešta) }\end{array}$ & $\begin{array}{l}\text { Maximilan Hell, } \\
\text { Remigio Döttler }\end{array}$ \\
\hline Terezijanišče & $1754-$ & $\begin{array}{l}\text { Janez Schöttl (1754-1757; 1762-1763); } \\
\text { Paul Mako (1757/1758-1774) }\end{array}$ & \\
\hline Univerza Gradec & $1763-1804$ & $\begin{array}{l}\text { Biwald (1755-1757 v Ljubljani); } \\
\text { Leopold von Wisenfeldt 1771-1773 }\end{array}$ & \\
\hline Univerza Buda & $1765-$ & Antun Radić $(1765,1766) ;$ Mako (1773-1782) & Franz Weiss (1777-1785) \\
\hline Univerza Pešta & & Radić & \\
\hline Univerza Praga & & Stanislus grof Wydra (-1804) & Joseph Stepling (1748-1778) \\
\hline Univerza Lvov & $1766-1799$ & $\begin{array}{l}\text { Scherffer (1773-1783); } \\
\text { Ignjat Martinović (1783-1791); Liesganig (1766-1799) }\end{array}$ & \\
\hline Univerza Trnava & $1761-1777$ & $\begin{array}{l}\text { Antun Radić (1763-1764): Ivan Horvat } \\
\text { (Horváth, 1767-1773) }\end{array}$ & Weiss (1761-1777) \\
\hline Univerza Innsbruck & $1772-1773$ & Franz Seraphin Zallinger & \\
\hline Višji študiji Ljubljana & $1760-$ & $\begin{array}{l}\text { Janez Schöttl (1759/60, 1760/61), } \\
\text { Janez Krstnik Pogrietschnig (1763-1769), } \\
\text { Gregor Schöttl (1768-1775) in njegovi študentje } \\
\text { Franc Samuel Karpe ter } \\
\text { Jurij Vega; Anton Ambschel (1773-1785) }\end{array}$ & \\
\hline Maribor & 1773-1787 & Janez Krstnik Kaschutnig & \\
\hline Višji študiji Novo mesto & $1803-1816$ & Teofil Zinsmeister pod vplivom Kastula Hieberja & \\
\hline Višji študiji Gorica & $1761-$ & $\begin{array}{l}\text { Jožef Kauffmann (1761-1762, 1772-1773): } \\
\text { Bernard Hohenwart (1769-1771); } \\
\text { Jožef Jakob Liberatus Maffei pl. Glattfort (1771) }\end{array}$ & \\
\hline Višji študiji Celovec & $1759-$ & $\begin{array}{l}\text { Janez Schöttl (1758/59); } \\
\text { Franc Ksaver Wulfen (1764-1805): } \\
\text { Leopold baron Apfaltrer (1765-1773) }\end{array}$ & \\
\hline $\begin{array}{l}\text { Univerza Pavia, } \\
\text { Univerza Milano }\end{array}$ & 1763 & Bošković osebno & $\begin{array}{l}\text { Paolo Frisi, Louis Lagrange, } \\
\text { Koprčan Gian Rinaldo grof Carli }\end{array}$ \\
\hline $\begin{array}{l}\text { Višji študiji Trst } \\
\text { in Rijeka }\end{array}$ & $\begin{array}{l}1767-1768, \\
1773-1784 \\
\end{array}$ & $\begin{array}{l}\text { G. Schöttl, Franjo Orlando, } \\
\text { Alois Capuano 1775-1782 }\end{array}$ & \\
\hline $\begin{array}{l}1778-1793 \text { predaval } \\
\text { teologijo v Zagrebu; } \\
1790-1804 \text { apostolski } \\
\text { misijonar v Kraljevini Ne } \\
1808-1809 \text { predaval teolo } \\
\text { Svetem Križu, predavatel }\end{array}$ & $\begin{array}{l}\text { eapelj, } \\
\text { ogijo pri } \\
\text { lj v Gorici. }{ }^{18}\end{array}$ & $\begin{array}{l}\text { Skotov podpornik Ambrozij Redeskini (Valentin Redescl } \\
\text { De Haidovio, Radeschini, * 21. 7. } 1746 \text { Ajdovščina; } \\
\text { OFMCap } 1765 ; \dagger 4.2 .1810 \text { Gorica) }\end{array}$ & \\
\hline
\end{tabular}




\section{Prodor novih kinetičnih teorij sestave snovi v obdonavski habsburški prostor}

Srednjeevropska jezikovno in duhovno mešana družba se je znova pokazala sprejemljivo za nove modele kemijske strukture snovi s kinetičnimi teorijami atomov koroškega Slovenca Jožefa Stefana in njegovega poglavitnega dijaka, soproga napol Slovenke Ludwiga Boltzmanna. Tudi to pot je smo bili priči praški izjemi Ernsta Macha, ki pa, kot vse izjeme, potrjuje pravilo, da se velike evropske ideje o kemijski strukturi snovi rade gojijo prav v izjemno heterogenem srednjeevropskem prostoru. Pozitivist Mach je svoje učence rad prav tako razpošiljal na pomembe položaje, vendar veliko manj uspešno od svojega nasprotnika Stefana. Stoletje potem ko je nastajajoča poznobaročna kemija nezadržno spolzela spod rok jezuitov v naročje sodobnejših znanstvenih mrež, se je Stefanu v borih nekaj letih posrečilo izpeljati podoben preobrat; le svojih starih študentskih nasprotnikov Ernsta Macha in Simona Šubica ni uspel ne spreobrniti, ne povsem spodriniti. Novodobni kinetični atomizem dunajske šole $\mathrm{v}$ marsičem ni bil daleč od Boškovićevih točkastih središč sil in jim je pomagal najti prostor v sodobni kvantni mehaniki. Jezuitska ljubljanska dijaka Franc Samuel Karpe in Jurij Vega sta na vplivnih dunajskih katedrah zgladila pot za domala zvezen prehod od svojih Boškoviću naklonjenih učbenikov do kinetične teorije in statistične mehanike. Pomešani narodi in tradicije Srednje Evrope so edini zmogli domala zvezno udejanjiti obe spremembi, ki se v drugih okoljih, denimo pri Kelvinovem navdušenju nad Boškovićem, kažejo bolj kot nenadni zasuki. Habsburško srednjeevropsko žezlo je bilo videti vsaj dvakrat izborno ozadje za spremembe v dojemanju kemijske strukture snovi. Ali bo še kdaj, to pot seveda brez cesarskega žezla?

\section{Zaključek}

Becher in nekdanji jezuit Born sta vsak v svojem stoletju usmerjala baročne vpeljave nove znanosti imenovane kemija v habsburški prostor. Med njunima dobama je zijal prepad kot ločnica med alkimijo in industrijsko-kmetijsko uporabo kemijskih dognanj. V habsburškem okolju so ta prepad premostili predvsem jezuiti odrasli ob rudarsko-industrijskih novodobnih naseljih spod Karpatov, med katere je spadal tudi Born. Čeravno slovenska rudarska naselja z Idrijo vred niso razvila tako pomembnih središč učenosti kot slovaška Banska Štiavnica, je napredek od Becherjeve dunajske terra pingus preko Stahlovega flogistona do sodobnejše Lavoisierjeve kemije Jacquina, Pankla in B. Hacqueta $v$ marsičem šel tudi skozi slovenska sita od Janeza Vajkarda kneza Turjaškega, preko njegovega občudovalca in soimenjaka Valvasorja do poglavitnega ljubljanskega lastnika rudnikov barona Žige Zoisa, zasebnega dijaka jezuitov Gabrijela Gruberja in Maffeija. Medtem ko je nastajajoča poznobaročna kemija nezadržno polzela spod rok jezuitov v naročje novodobnih prostozidarjev vrste nekdanjega jezuita Borna, se je skozi jezuitski labodji spev skristalizirala mogočna Boškovičeva teorija neskončno deljive točkaste snovi, ki je v nekaj letih dobesedno preplavila Habsburški prostor z nekaj izjemami v J. Steplingovi zlati Pragi in M. Hellovem cesarskem Dunaju. Narodnostno in idejno mešana struktura Donavske monarhije pod habsburškim srednjeevropskim žezlom se je izkazala kot idealno okolje za tovrstne bliskovite spremembe $\mathrm{v}$ dojemanju kemijske strukture snovi, kar se je znova posrečilo stoletje pozneje s kinetičnimi teorijami atomov koroškega Slovenca Jožefa Stefana in njegovega poglavitnega dijaka, soproga napol Slovenke Ludwiga Boltzmanna. Tudi to pot je smo bili priči praški izjemi Ernsta Macha, ki pa, kot vse izjeme, potrjuje pravilo, da se velike evropske ideje o kemijski strukturi snovi rade gojijo prav v izjemno heterogenem srednjeevropskem prostoru.

\section{Summary}

\section{Jesuits Chemists of Hapsburg Monarchy}

The achievements of the Jesuits from the Austrian and Bohemian provinces, who have published books on chemistry are focused. Their links with the area of today's Slovenia are particularly exposed. The guidelines which have enabled prompt victories of the ideas about the structure of matter of Jesuit Ruđer Bošković are indicated. Johann Joachim Becher and former Jesuit Ignaz von Born directed baroque introduction of a new science called chemistry in the Habsburg space each in his own century. Between their achievements there was a great intellectual gap as the dividing line between the alchemy and industrial-agricultural use of chemical knowledge. In the Habsburg environment, this gulf bridge was trespassed in particular with the Jesuits grown up with modern mining and industrial estates beneath the Carpathians, with the magnificent freemason Born as one of them in Transylvania. Although Slovenian mining town of Idrija did not develop such important center of learning such as Slovakian Banska Štiavnica, the progress of Becher's Viennese terra pingus through Georg Ernst Stahl's phlogiston to modern Lavoisier's chemistry of Jacquin, Pankl and B. Hacquet in many ways went through the sieve of the Slovenian magnates and masters of chemistry. The very first and best of them was Johann Weikhard Prince Auersperg, through his admirer and namesake Valvasor, until the Carniola MineOwner crystallographer baron Žiga Zois. It was no coincidence that Auersperg's confessors and home tutors were Jesuits of some fame. All formal Valvasor's studies were the Jesuit ones and Zois was a private student of Jesuits 
Gabriel Gruber and Maffei. The inconceivable fast success of Bošković's adherents in the Hapsburg monarchy of Zois' juvenile days is comparable with a similar rapid introduction of the kinetic theories of atoms of Slovene Jožef Stefan and Ludwig Boltzmann in the same geographical area a century later. Boltzmann was not only Stefan's best student, but he also married a half Slovenian maid. Even the exemptions which prove the rule were the same in both cases, the Prague Clementinum of Joseph Stepling and its descendant of positivist anti-atomist Ernst Mach. The national and with it also the spiritual mixture of Danube Monarchy under Habsburg Mid-European rule proved to be the ideal frame for such scientific blitzkriegs until the ill-famous Anschluss destroyed it for the generations to come.

\section{Literatura}

1. A. G. Debus, Alchemy and Early Modern Chemistry: Papers from Ambix, Jeremy Mills Publishing, 2004, str. 427; M. Baldwin, Alchemy and the Society of Jesus in the Seventeenth Century: Strange Bedfellows? Ambix, 1983, 40/2, str. 41.

2. Baldwin, 1983, str. 43.

3. Baldwin, 1983, str. 58.

4. T. Cevae, Philosophia novo-antiqua, Milano: Dominici Bellagattæ, 1718, str. 1, 14, 67, 90; L. Galler, Tractatus de Creatione mundi, Viennae, 1718, str. 2, 25, 28, 33, 66, 67, 70.

5. A. Gabon, Carmine Elegaico; Physica Exotica, seu Secreta naturae et artis, Trnava, 1717.

6. J. Franz, Dissertatio de natura electri, Viennae 1751; J.N. Stoeger, Scriptores Provinciae Austriacae Societatis Jesu ab ejus origine ad nostra usque tempora. Collectionis scriptorum ejusdem Societatis universae. Viennae: Typis congregationis Mechitharisticae. Tomus I-II, 1855, str. 86; C. Sommervogel, Bibliothèque de la Compagnie de Jésus, Première partie: Bibliographie par les Pères Augustin et Aloys de Backer, Nouvelle Édition par Carlos Sommervogel, S.J. Strasbourgeois, Tome I-IX. Bruxelles-Paris: Province de Belgique, 1890-1900, 3: 948-950.

7. J. Bartakovics, Metallurgicon seu de Cultura fodinarum auri et argenti Libri II. Carmen cum Indiculo Vocabulorum Quorondum ad Aurariam Argentariamque spectantum Partes II. Trnava, 1748.

8. F. Ginthör, promocija Boškovićeve Dissertatio de inaequalitate gravitatis in diversis terrae locis, Viennae 1751 (prva izdaja Rim 1741); F. Ginthör, promocija Boškovićeve Disser- tatio de viribus vivis... honoribus perillustris domini Caroli de Teuttern, dedicata, Viennae: Kaliwoda, 1752, skupaj z Franzem Gusmanomin jezuitom poznejšim rektorjem na Dunaju, Gradcu in Linzu Josephom Gundlom 1710-1770 (prva izdaja Rim 1745); Sommervogel, 1890-1900, 3: 1419; Stoeger, 1855, str. 98-99.

9. http://www.musiklexikon.ac.at/ml/musik_R/Reutter_ Familie.xml

10. J. Fridvalski, Mineralogia Magni Principartus Transilvaniae, seu ejus metalla, semi metalla, supophura, salia, lapides et aquae, Cluj, 1767, str. 25, 102, 103, 105, 120, 132, 134137, 152, 174, 189.

11. J. Fridvalski, Dissertatio de Skumpia seu Cotino planta coriaria cum diversis experimentis in M. principatu Transylvania institutis, Cluj, 1773, str. 23.

12. M. Pankl, Compendium Institutionum Physicarum I: Corpore abstracte II: De Corpore Chemice Considerato III: Physice. Bratislava 1790, Adjustum et ad systema antiphlogisticum accomodatium, Bratislava, 1793, Buda 1797-1798; Matthaeus Pankl, Compendium Oeconomia Ruralis, Buda, 1790; 1793; 1797; I. Horváth, Elementae Physicae, 1790; C. Villeneuve, Rudolf Steiner: the British Connection: Elements from His Early Life, Temple Lodge Publishing, 2011, str. 365; J. Zemplén, The Reception of Copernicanism in Hungary, The Reception of Copernicus' heliocentric Theory - on the borders, (ur. J. Dobrzycki), 2013, str. 355.

13. N. Poda von Neuhaus, Berechnung der Luftmaschine, 1771; P.P. Aspaas, Maximilian Hell. Doktorat Tromsouit, 2012, str. 90.

14. F .S. G. Eder; N. Poda von Neuhaus, Syllabus Fossilium, Vienna, 1776; J.N. Stoeger, Scriptores Provinciae Austriacae Societatis Jesu ab ejus origine ad nostra usque tempora. Collectionis scriptorum ejusdem Societatis universae. Viennae: Typis congregationis Mechitharisticae. Tomus I-II, 1855, str. 69.

15. Lemberger Zeitung, 16.9.1818, prva stran.

16. Joannes Christophorus Stelzhamer, Ludwig Wilhelm Gilberts Annalen der Physik, 1808, 30; 1809, 31:.

17. C. Hieber, Theses selectiores ex philosophia. Pedemontium, 1799, str. 8; T. Zinsmeister, Tractatus ex Physica. Rokopis v Ljubljanski frančiškanski knjižnici 1 d 48, 1799; C. Hieber, Philosophia Corporum seu Physica: Pars i generalis ex variis / Novissimis Autoribus con gesta ac Systemate ordinata pro annis Praelectionibus P. Castuli Huber, Rokopis v Ljubljanski frančiškanski knjižnici 15 b 65, 1797.

18. V. Škafar, Knjige in knjižnica v nekdanjem kapucinskem samostanu v Mariboru (1613-1784). Časopis za zgodovino in narodopisje, 1993, 64/1: 81. 


\section{Abstract}

The achievements of the Jesuits from the Austrian and Bohemian provinces, who have published books on chemistry are focused. Their links with the area of today's Slovenia are particularly exposed. The guidelines which have enabled prompt victories of the ideas about the structure of matter of Jesuit Ruđer Bošković are indicated. Inconceivable fast spread of Bošković's adherents in the Hapsburg monarchy is compared with a similar rapid introduction of the kinetic theories of atoms of Slovene Jožef Stefan and Ludwig Boltzmann in the same geographical area. Boltzmann was not only Stefan's best student, but he also married a half Slovenian maid.

Keywords: Jesuits, Hapsburg Monarchy, History of Chemistry, Ruđer Bošković, Jožef Stefan, Ludwig Boltzmann 